\title{
Subduction Zone Backarcs, Mobile Belts, and Orogenic Heat: COMMENT
}

\section{David D. Blackwell}

Dept. of Geological Sciences, Southern Methodist University, Dallas, Texas 75275-0395, USA, blackwel@smu.edu

In their paper Subduction zone backarcs, mobile belts, and orogenic heat, Hyndman et al. (2005) provide a global overview and emphasize the importance of heat flow and thermal structure in understanding the deformation behavior of continents. They develop the model of a broad mobile zone due to backarc heating as a controlling factor on Cordilleran tectonic behavior. They also focus on the general lack of correspondence of extension with the high heat flow in backarcs. However, they neglected to cite previous work in western North America relating to these concepts.

For example, Hyndman et al. (2005) state in the abstract and in the text without reference that continental backarcs have hot and thin lithospheres, not just those with active extension. Blackwell (1969) discovered that the heat flow in the U.S. Pacific Northwest was statistically identical to that in the Basin and Range Province in spite of the differences in late Cenozoic tectonic style. Blackwell (1969) also noted that White and Savage (1965) had found a similar crustal structure and Pn velocity in Southern British Columbia to that attributed to active extension in the Basin and Range (see Fig. 1 in that paper). Blackwell (1969) defined the Cordilleran Thermal Anomaly Zone (CTAZ) to in-

doi: 10:1130/1052-5173(2005)015<e8:SZBMBC >2.0.co;2 clude those areas of disparate tectonic history from the southwestern United States into southern British Columbia with similar, high heat flow.

In 1969, based on a preprint of the pioneering work of Atwater (1970), we realized that the CTAZ represented a subduction zone backarc in various stages of evolution and described and illustrated thermal and crustal cross sections similar to those shown in Hyndman et al. (2005). The thin crust, low Pn velocities, thin lithosphere, and thermal contrast between the craton and the subduction zone outer arc were shown in detail (see Fig. 1, one of 3 such sections from Roy et al., 1972; see also Blackwell, 1971). The subject was further discussed by Blackwell (1978) and by Blackwell (1983).

After describing their global survey of backarcs, Hyndman et al. (2005, p. 5) summarize the two principal indicators of high temperature ...: (1) Surface heat flow greater than $\sim 70 \mathrm{~mW} / \mathrm{m}^{2}$ (for normal upper crust heat generation of $1.0-1.5 \mu \mathrm{W} / \mathrm{m}^{3}$ ) ... and (2) low seismic velocities in the upper mantle.... No reference was to given Blackwell (1969), Blackwell (1971), and Roy et al. (1972) in spite of the fact that they first emphasized that exact conclusion many years ago.

The Hyndman et al. (2005) section Duration of High Temperatures in Mobile Belts contains extensive discussion of the spatial and temporal behavior of the heat flow pattern in the Cordillera and of the sources of the heat in a back arc. The arguments and conclusions are similar to those given in Blackwell (1978, and 1983). For example Blackwell et al. (1978) stated that for the CTAZ the mantle heat flow

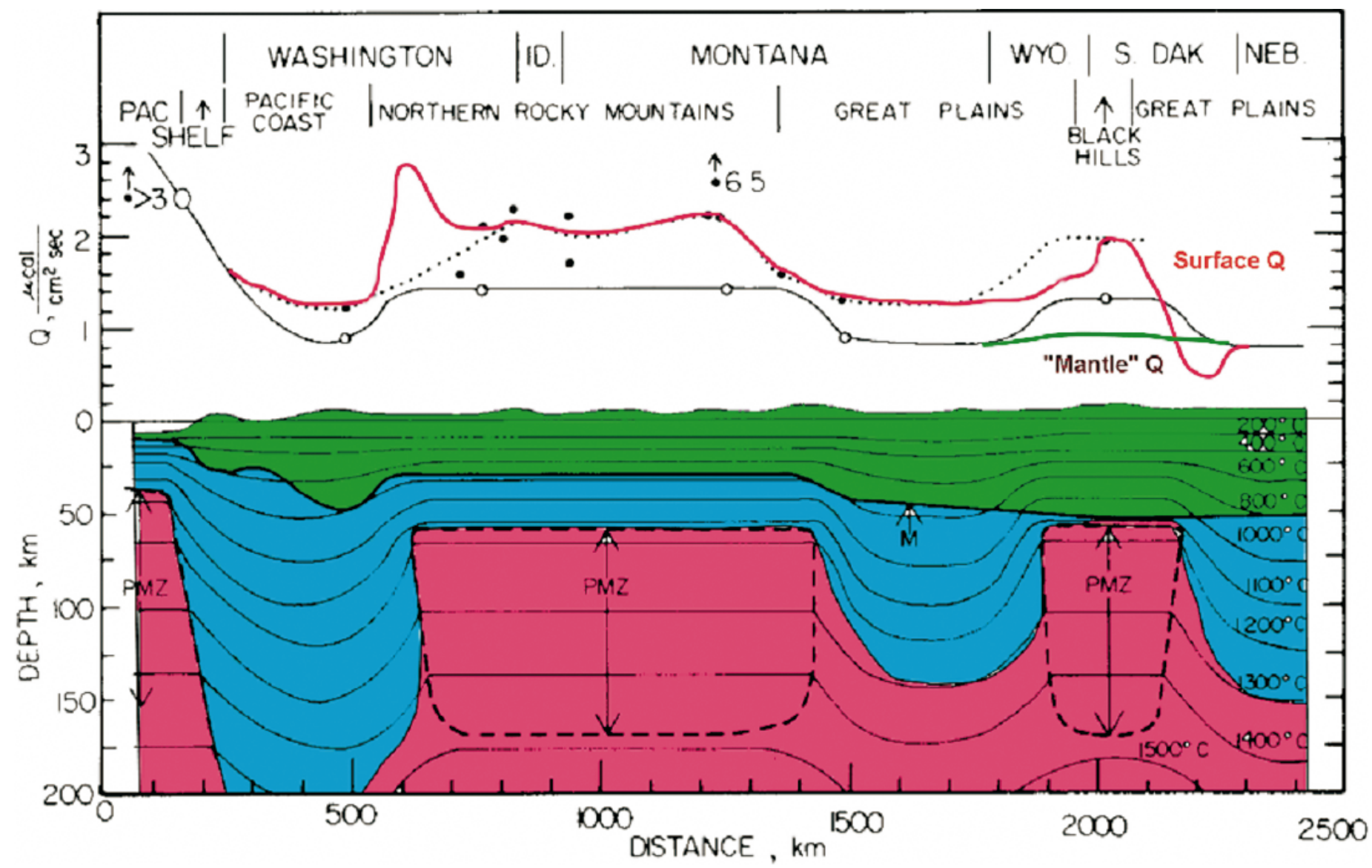

Figure 1. Cross section of U.S. Pacific Northwest at $\sim 47^{\circ} \mathrm{N}$ from Roy et al. (1972, their Figure 18), modified with color added. Solid dots represent surface heat flow and circles represent reduced heat flow. PMZ-partial melt zone (low velocity zone). Crust is green, mantle lithosphere is blue, and asthenosphere is red. Heat flow lines in color represent pattern as presently understood (Blackwell and Richards, 2004). 


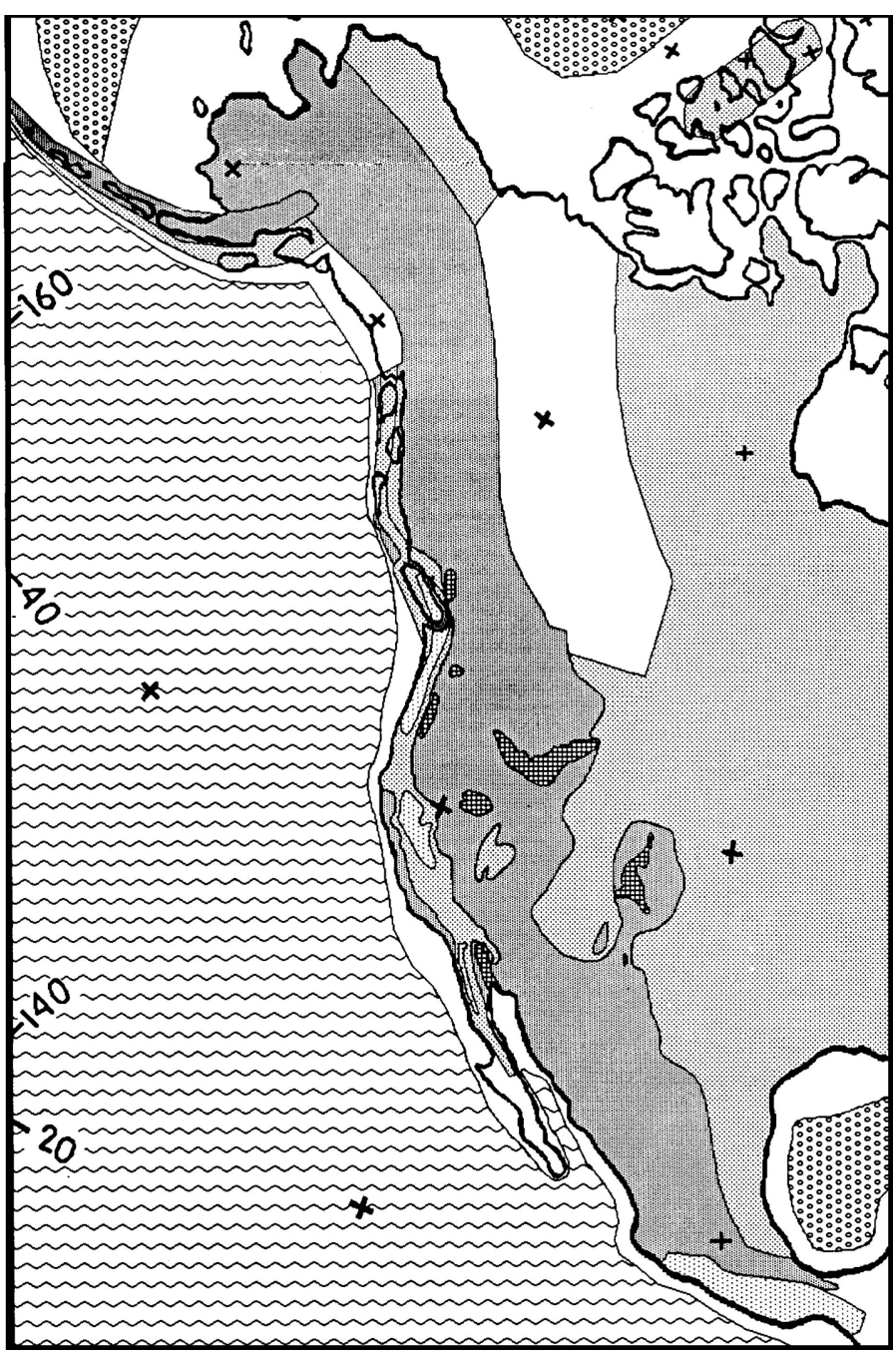

Figure 2. Part of the index map for the GSA Decade of North American Geology Geothermal Map of North America (Blackwell and Steele (1992). Areas of continent with heat flow that is normal are shown by the intermediate density dot pattern. Areas of heat flow equal to, or below, normal in tectonic areas are shown by the low density dot pattern. Areas of heat flow that are typical of the CTAZ $\left(Q s\right.$ of $80 \mathrm{~mW} / \mathrm{m}^{2}$ ) are shown by the high density dot pattern. Areas with very high heat flow (generally greater than $100 \mathrm{~mW} / \mathrm{m}^{2}$ ) are shown by the cross hatched pattern.

has remained anomalous even after the end of the thermal event most obvious at the surface.

The CTAZ appears prominently on the uncited Geothermal Map of North America published in 1992 by the Geological Society of America as part of their Decade of North American Geology series
(Blackwell and Steele, 1992, see also Blackwell and Richards, 2004). In the accompanying descriptive paper (Blackwell et al., 1991), the tectonic provinces of western North America were categorized as to their plate setting; i.e., outer arc/backarc, etc. The crustal structure investigations in Canada and Alaska in the past 10 years have proved the validity of these inferences.

In their discussion, Hyndman et al. (2005) have omitted the important role that the cold, strong outer-arc blocks have played on the tectonic behavior along the west coast of North America. The proof that continental subduction zones have low heat flow and low friction along the thrust plane presented by Ziagos et al. (1985) clearly allows the association of the low heat flow in the Sierra Nevada Mountains (for example) to the subduction history along the west coast of North America.

\section{REFERENCES CITED}

Atwater, T., 1970, Implications of plate tectonics for the Cenozoic evolution of western North America: Geological Society of America Bulletin, v. 81, p. 3513-3536.

Blackwell, D.D., 1969, Heat flow in the northwestern United States: Journal of Geophysical Research, v. 74, p. 992-1077.

Blackwell, D.D., 1971, Thermal structure of the continental crust, in Heacock, J.G., ed., The structure and physical properties of the Earth's crust: Washington, D.C., American Geophysical Union Monograph 14, p. 169-184,

Blackwell, D.D., 1978, Heat flow and energy loss in the Western United States, in Smith, R.B., and Eaton, G.P., eds., Cenozoic tectonics and regional geophysics of the western Cordillera: Geological Society of America Memoir 152, p. 175-208.

Blackwell, D.D., 1983, Heat flow in the northern Basin and Range province, ed. G. P. Eaton, in The role of heat in the development of energy and mineral resources in the northern Basin and Range Province: Geothermal Resources Council Special Report 13, p. 81-92.

Blackwell, D.D., and Richards, M., editors,2004, Geothermal Map of North America: American Association of Petroleum Geologists, scale 1: $6,500,000$

Blackwell, D.D., and Steele, J.L., 1992, Geothermal Map of North America: Geological Society of America, Decade of North American Geology Map, scale $1: 5,000,000$

Blackwell, D.D., Steele, J.L., and Carter, L.S., 1991, Heat flow patterns of the North American continent: A discussion of the Decade of North American Geology Geothermal Map of North America, in Slemmons, D.B., Engdahl, E.R., Zoback, M.D., and Blackwell, D.D., eds., Neotectonics of North America: Geological Society of America, Decade of North American Geology, Map Volume 1, p. 423-436,

Hyndman, R.D., Currie, C.A., Mazzotti, S.P., 2005, Subduction zone backarcs, mobile belts, and orogenic heat: GSA Today: v. 15 , no. 2, p. 4-10. doi: 10:1130/1052-5173(2005)015<4:SZBMBA > 2.0.co;2.

Roy, R.F., Decker, E.R., and Blackwell, D.D., 1972, Continental heat flow, in Robertson, E.C., ed., The nature of the solid Earth: New York, McGraw-Hill, p. 506-543. (http://www.smu.edu/geothermal/heatflow/ continental_heatflow.pdf)

White, W.R.H., and Savage, J.C., 1965, A seismic refraction and gravity study of the Earth's crust in British Columbia: Bulletin of the Seismological Society of America, v. 55, p. 463-486.

Ziagos, J.P., Blackwell, D.D., and Mooser, F., 1985, Heat flow and subduction in southern Mexico: Journal of Geophysical Research, v. 90, p. $5410-5420$

MANUSCRIPT SUbmitTed 4 APRIL 2005; PUblished online August 2005. 